\title{
MANIFESTAÇÕES PATOLÓGICAS EM HABITAÇÕES DE INTERESSE SOCIAL CONSTRUÍDAS COM O SISTEMA LIGHT WOOD FRAME NO SUL DO BRASIL
}

RODRIGO VARGAS SOUZA, Dr. | UFSC

LISIANE ILHA LIBRELOTTO, Dra.| UFSC

ÂNGELA DO VALLE, Dra. | UFSC

\section{INTRODUÇÃO}

Nos últimos anos vem crescendo o uso do sistema construtivo Light Wood Frame (LWF) no sul Brasil, principalmente, para construção de Habitações de Interesse Social (HIS). Assim este trabalho analisou o desempenho técnico-construtivo e as manifestações patológicas ocorrentes nas edificações no sul do Brasil. O método utilizado baseou-se em multimétodos, já consagrados nas áreas de Avaliação Pós-Ocupação (APO), engenharia diagnóstica e restauro das edificações. $O$ método leva em consideração o ponto de vista dos especialistas (arquitetos, construtores e pesquisadores), mas também a satisfação dos usuários, para diagnosticar aspectos a corrigir das habitações estudadas. Foram utilizados procedimentos de inspeção tradicionais e elaboraram-se mapas de danos, ferramentas comuns no restauro de edificações. Os resultados apontam as principais manifestações patológicas ocorrentes nas Habitações de Interesse Social construídas com Light Wood Frame no Sul do Brasil. As origens das manifestações patológicas são decorrentes de todas as etapas (projeto, construção e utilização) do ciclo de vida das edificações. A etapa que mais gerou as manifestações patológicas, foi utilização (uso e manutenção), mas também, foram identificadas uma quantidade significativa com origem nas etapas de projeto e execução (Figura 1).

Origem das manifestações patológicas

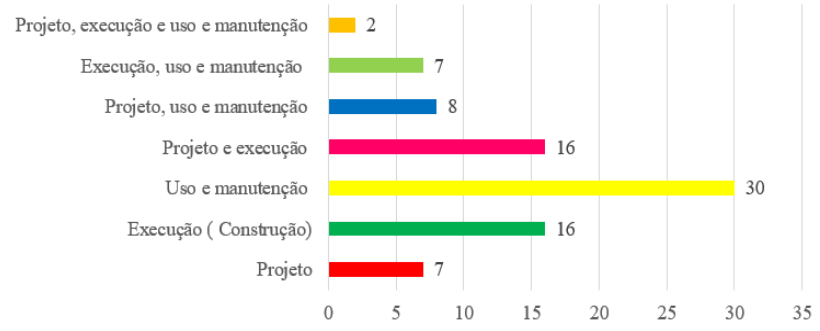

Figura 1: Sístese da origem das manifestações patológicas nas HIS Fonte: Autor
A maior parte das manifestações patológicas identificadas ocorrem nos revestimentos internos e externos do subsistema parede. Os agentes geradores das manifestações patológicas nas edificações foram: agentes humanos (furos e desgastes causados por impacto, abrasão, esforços e movimentos gerados pelos usuários e falhas no detalhamento do projeto e na construção), agentes mecânicos (vento e granizo), agentes químicos (água, condensação, sais e poeiras), agentes eletromagnéticos (radiação solar) e agentes biológicos (fungos e cupim). A Figura 2 apresenta o pencentual de cada um destes agentes que, diretos e indiretos, atuaram para geração das manifestações patológicas das HIS.

Figura 2: Agentes que atuaram sobre os subsistemas das HIS Fonte: Autor 
